\title{
Quantitative Analysis of Myofascial Pain Syndrome in Trapezius Muscle Using Pressure Algometer and Surface Electromyography
}

\author{
Shin-Hye Kim¹, Yu-Min Ko², Ji-Won Park³, Jong-In Youn ${ }^{1}$ \\ 'Department of Biomedical Engineering, Daegu Catholic University, Daegu, Republic of Korea; ${ }^{2}$ Department of Physical Therapy, Gangneung \\ Yeongdong University, Gangneung, Republic of Korea; ${ }^{3}$ Department of Physical Therapy, Daegu Catholic University, Daegu, Republic of Korea
}

Purpose: Myofascial syndrome is a chronic muscle pain caused by repetitive motions with stress-related muscle tension. This study aimed to investigate the validity and reliability of the evidence for diagnosing myofascial pain syndrome in trapezius muscle using a pressure algometer and surface electromyography.

Methods: The experiments were performed using a total of 10 subjects, and the target locations were determined by means of a pressure algometer in the right upper trapezius muscle. The part with the lowest pain value as the trigger point and the part with the highest pain value as the non-pain trigger point were selected for measuring the locations. The median frequency and average frequency were measured in those locations with electromyography. To check the muscle fatigue, the upper trapezius muscle was moved up and down for 2 seconds at 5-second intervals in 30 seconds. The measured values were evaluated using the independent paired t-test and MannWhitney U-test.

Results: The median frequency at the non-trigger point (13.7) was significantly higher than that at the trigger point (7.3). Furthermore, the mean frequency (14.7) at the non-trigger point was significantly higher than that at the trigger point (6.3).

Conclusion: The results showed the correlations between the trigger points of the muscle pain and frequency analysis of surface electromyography. Thus, this study may be possible to use as a diagnostic tool for myofascial pain syndrome.

Keywords: Myofascial pain syndromes, Trigger points, Electromyography

\section{서 론}

근막통증증후군(myofascial pain syndrome)은 근막 통증유발점(trigger point)에 의해 발생하는 근육 질환으로 뒷목과 허리 근육 부위에 짓누르는 통증을 느끼고, 해당 근육을 손으로 압박하면 국소적인 통 증과 연관통(referred pain)을 유발한다.1,2 또한 근막통증증후군은 근 육 피로도를 자극시킨다. 근막통증증후군 환자의 경우 강도 높은 운 동이나 지속적인 근육의 사용으로 ${ }^{4}$ 근섬유 내 흥분(excitation)이 발 생하며 수축과 이완을 반복하는 상태가 지속된다. 이러한 근섬유의 자극으로 인해 세포질의 칼슘이온(Ca2+)이 방출되고 트로포닌(troponin)에 칼슘이온이 결합되어 섬유 내 근절(sarcomeres)의 수축과 이 완 반복으로 수축결절(contraction knot)과 팽팽한 밴드(taut band)가 생성된다.,5근섬유 내 수축결절이 분포된 형태를 통증유발점이라고

Received Sep 15, 2021 Revised Oct 26, 2021

Accepted Oct 28, 2021

Corresponding Jong-In Youn

E-mail jyoun@cu.ac.kr
하는데, 이 과정에서 낮은 주파수 피로도(low frequency fatigue)가 발 생하며, 5 동시에 생리학적 기전으로 과부하된 근절이 수축 상태를 지 속하게 된다. 근막 통증유발점은 골격근의 팽팽한 밴드(taut band)에 위치하고 근육섬유의 초기 손상 후 발달하며, 손상은 근육에 대한 반복적인 움직임과 뚜렷한 외상에 의해 나타난다. 근막 통증유발점 은 근육과 근섬유 내 통증과 스트레스를 발생시키며 이러한 스트레 스의 증가로 추가적 활성이 나타나기 쉬운 상태가 된다. ${ }^{6}$ 근막 통증유 발점은 활동형(active) 또는 잠재형(latent)으로 나뉜다. ${ }^{67}$ 활동형 근막 통증유발점은 시간경과에 따라 자발적이고 지속적인 통증과 관련이 있는 반면에 잠재형 근막 통증유발점은 자극이 주어졌을 때만 통증 이 발생한다. 이는 환자의 주관적인 통증 인지 여부에 따라 활동형 근 막 통증유발점, 잠재적 근막 통증유발점을 구분하는 것으로 근막 통 증유발점을 진단하는 근거의 타당성과 신뢰성이 미흡함을 의미한다. ${ }^{8}$ 
이러한 통증유발점의 주된 진단 방법은 손가락 촉진(palpation)법 으로 근육 통증 부위를 밀거나 집는 방식으로, 촉진의 종류로 평촉진 (flat palpation), 꼬집기 촉진(pincer palpation)이 있다. 평촉진은 손끝으 로 진단 부위를 밀어 통증유발점을 확인하는 방법이고, 꼬집기 촉진 은 손끝을 핀셋모양으로 하여 진단 부위를 잡아서 확인하는 방법이 다. ${ }^{9}$ 이러한 촉진법은 물리치료사의 주관적 진단확인 등으로 정량적 인 측정이 불가피한 한계점이 있다. 또 다른 진단 방법에는 압통역치 측정방법과 생체신호인 근전도신호를 이용한 방법 등이 있다. 압력 통각계는 근막통증증후군의 압통역치(pressure pain threshold)를 정 량적으로 평가할 수 있는 객관적인 평가 도구이며, 신뢰도가 매우 높 은 측정기법이다. ${ }^{10}$ 압통역치는 통증의 한계점 및 불편감을 일으키는 최소한의 압력을 의미한다. 압력통각계를 활용하여 통증유발점에서 의 압통역치를 확인하기 위해서는 동일한 위치에서 반복적 기록을 측정해야 하고, ${ }^{1}$ 압력통각계의 계기상 측정되는 수치는 $\mathrm{lb}, \mathrm{N}, \mathrm{kg}$ 등 의 단위로 구성된다. Fischer ${ }^{12}$ 와 Kelly-Martin ${ }^{13}$ 의 연구는 압력통각계 신뢰성에 관한 증거로 많이 인용되며 정보를 객관적으로 수집할 수 있는 도구로 설명하였다. 압력통각계가 개발된 후 근막통증증후군 환자 평가 도구로써 적합성과 나이의 상관관계, 성별 비교, 활동성과 비활동성 역치 값 등에 대한 많은 연구들이 존재한다. ${ }^{12,22}$ 본 연구에 서는 근육통증증후군의 진단에 사용되는 압력통각계를 활용하여 연구대상자들의 위등세모근에서 통증유발점과 비통증유발점 부위 를 정하고 반복측정을 통해 객관적인 결과를 도출하고자 하였다.

근육의 피로도를 확인하기 위해 통상적으로 이용되는 방식은 표 면전극을 이용한 근전도 측정법이다. 표면 근전도(surface electromyography)는 피부 표면에 일회용 전극을 부착하여 비침습적이고 통증 이 없는 방식으로 생체 신호를 획득한다. ${ }^{14}$ Vøllestad 등 ${ }^{5}$ 은 근육 피로 도를 운동에 의한 힘 또는 출력 생성능력의 감소라고 정의하였다. 근 육 피로는 특정 근육을 과도하게 사용하거나 일정 동작을 반복적으 로 수행할 시 근육 내 피로물질이 쌓여 발생된다. 근전도 신호의 진폭 을 반영하여 root mean square (RMS)값의 수식과 평균 주파수(mean frequency, MNF) 또는 중앙 주파수(median frequency, MDF)는 근육 피로도를 확인하는 가장 일반적인 방법이다. ${ }^{15} \mathrm{RMS}$ 는 시간의 흐름에 따라 근육 사용여부와 힘에 관한 정보를 나타내는 변수로, 근전도의 원 신호(raw signal)를 변형하지 않고 수학적인 방법으로 쉽게 계산할 수 있다. ${ }^{16}$ 다만, 근전도 신호의 진폭을 반영한 RMS값을 구하는 방식 은 근육의 길이와 수축력이 변하는 역동적인 운동에서 근전도의 진 폭과 근수축력의 일관성이 없어 잘 이용되지 않는다. ${ }^{17}$ 평균 주파수 와 중앙 주파수의 방법은 획득한 시간영역의 근전도 신호에 주파수 영역으로 변환해주기 위해 고속 푸리에 변환(fast fourier transformation)을 적용하면 근육 피로 정보를 추출할 수 있다.5,15 평균 주파수는 특정 구간에서의 주파수 평균을 의미하고 중앙 주파수는 파워 스펙 트럼(power spectrum) 내에서 두가지 영역으로 나뉜 주파수 값을 스 펙트럼의 중심 위치에 나타내는 척도로 사용된다. 주파수 영역분석 은 전극에 의한 영향이 비교적 적고, 생화학적, 생리학적 변화에 관계 가 깊다.5,15 스펙트럼 분석에 의하면 운동 시 근육 피로도에 따라 고주 파 영역은 감소하고 저주파 영역은 증가하여 주파수 스펙트럼이 저 주파 대역으로 이동한다. ${ }^{18}$ 따라서 근육피로도가 쌓이게 되면 근전도 는 저주파로 이동하며 평균 주파수와 중앙 주파수가 감소하는 현상 을 보인다. 주파수 스펙트럼이 저주파 대역으로 이동하는 것은 근육 의 피로함을 나타낸다. 평균 주파수와 중앙 주파수는 주파수 분석에 서 일반적으로 근육 피로도의 징후로 사용되며 중앙 주파수의 경우 잡음에 강하고 근육 관련 변수들에 대해 신뢰할 수 있는 지표로 알려 져 있다. 평균 주파수와 중앙 주파수 비교 시 중앙 주파수 값이 일관 성을 가지고 신뢰성이 있어 많이 사용되는데, ${ }^{5,16}$ Wytrążek과 Juliusz ${ }^{23}$ 는 압력통각계와 표면 근전도를 사용하여 통증유발점의 존재를 확 인하는 연구하였다. 같은 방법을 사용한 다른 연구에서도 근전도의 진폭만을 분석하여 근육피로를 확인하였다. 따라서 본 연구에서는 압력통각계를 이용하여 압통역치를 정량적으로 살펴본 후, 표면근 전도를 이용하여 근육의 사용여부를 확인하는 RMS를 바탕으로 평 균주파수와 중앙주파수 분석을 통해 통증유발점과 비통증유발점 에서의 근피로도를 비교하고자 하였다. 이를 통해 근막통증증후군 을 진단할 수 있는 도구로 사용될 수 있는지 알아보고자 하였다.

\section{연구 방법}

\section{1. 연구대상}

본 연구는 위등세모근의 통증을 호소하여 근막통증증후군으로 의 심되는 20대 10 명(남자 6 명, 여자 4명)을 대상으로 실험을 진행하였다 (Table 1). 모든 연구대상자에게 실험을 실시하기 전 연구에 대해 충분 히 설명하였고 참여대상자들은 모두 서면동의 하였다. 그리고 본 연 구는 C대학교의 생명윤리위원회에 의해 연구윤리승인을 받아 실험 을 수행하였다(승인번호: CUIRB-2021-0009). 연구대상자 선택기준은 실험에 영향을 주는 약물을 복용하지 않은 자, 측정부위 관련 수술 이나 치료를 받지 않은 자, 그리고 근력운동을 과도하게 수행해 오지 않은자로 지정하였다.

Table 1. General characteristics of subjects

\begin{tabular}{|c|c|c|c|}
\hline \multirow{2}{*}{ Index } & Male $(n=6)$ & Female $(n=4)$ & \multirow{2}{*}{$p$} \\
\hline & \multicolumn{2}{|c|}{ Mean $\pm S D$} & \\
\hline Age (yr) & $23.2 \pm 0.98$ & $24.5 \pm 1.29$ & 0.100 \\
\hline Heigh (cm) & $176.5 \pm 6.53$ & $159 \pm 2.71$ & 0.001 * \\
\hline Weight (kg) & $69.5 \pm 8.62$ & $54.8 \pm 4.92$ & $0.02^{*}$ \\
\hline
\end{tabular}

${ }^{*} p<0.05$ 


\section{2. 측정도구 및 방법}

1) 압통역치 측정

측정기기는 Commander Echo Algometer (JTECH Medical Industries Inc., USA)를 사용하였으며, 통증을 유발하는 작용기에 팁이 달려있 는데, 이것은 압력을 가할 때 발생하는 통증을 최소화하기 위해 패드

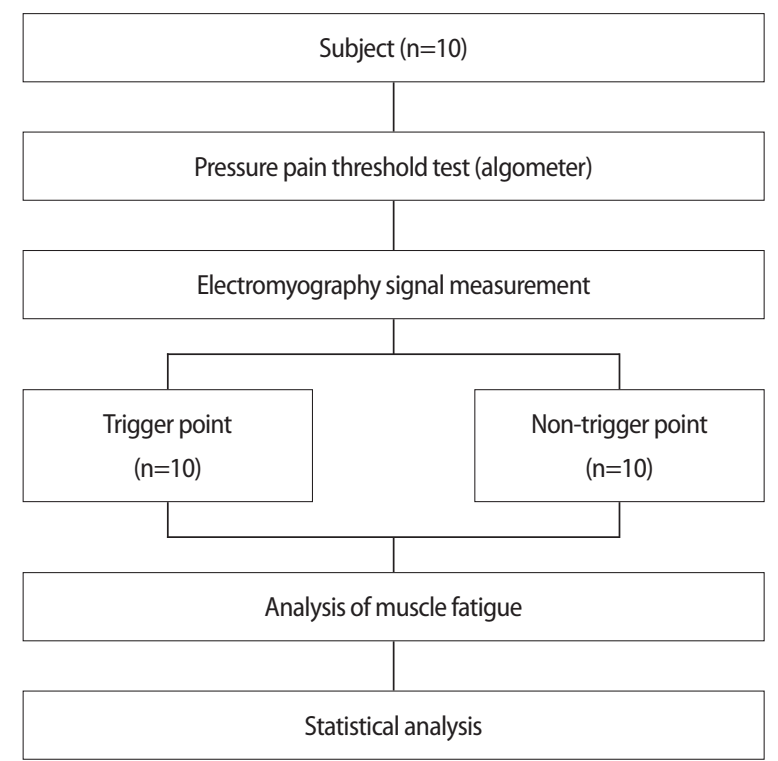

Figure 1. Diagram of experimental process.
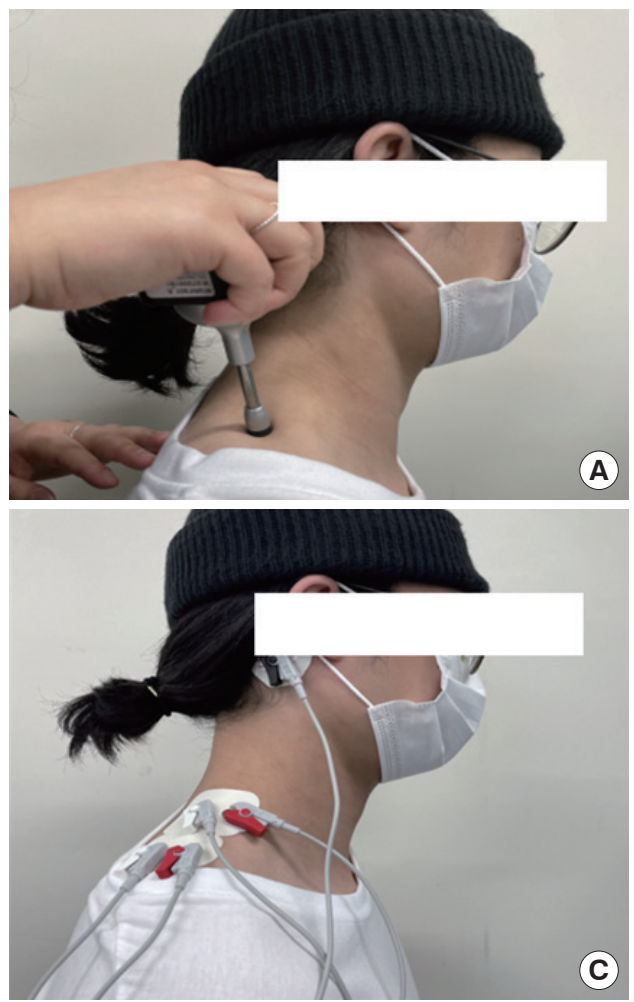

A)
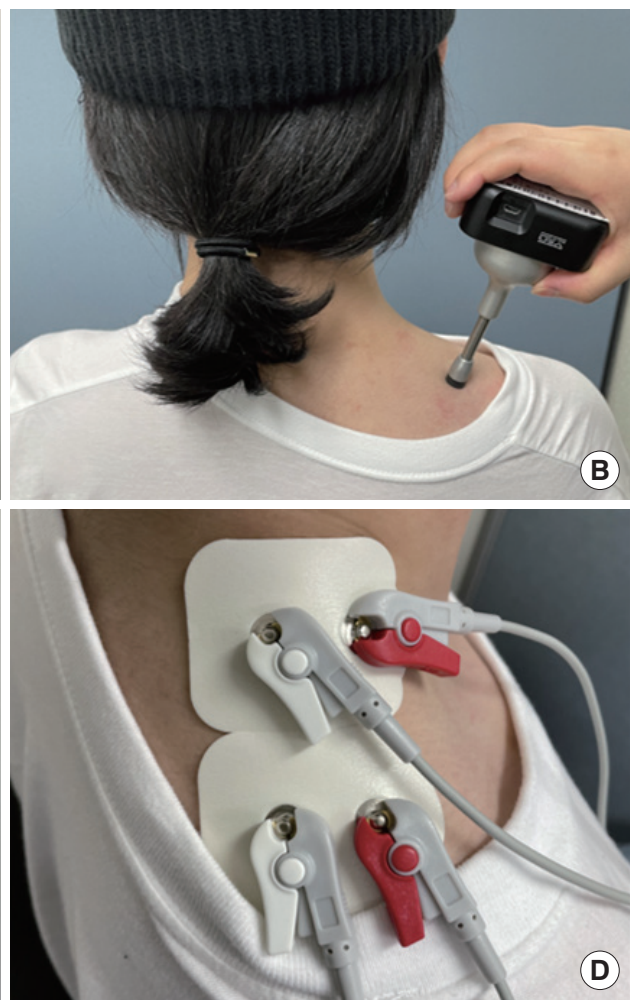

Figure 2. Myofascial trigger point measurement locations (A), (B): Pressure algometer location, (C), (D): EMG location. 

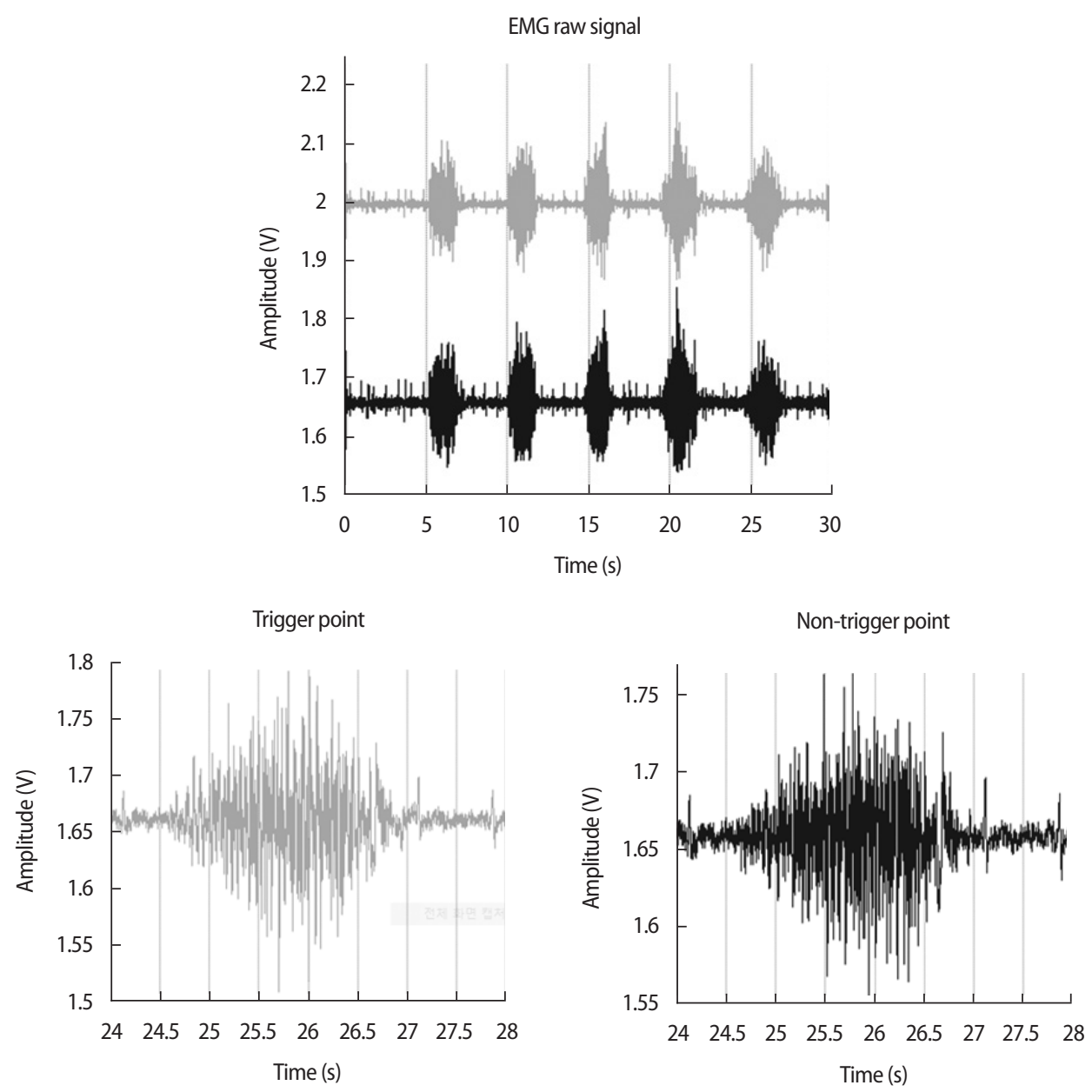

Figure 3. EMG raw signals of trigger and non-trigger points.

Ver. 1.0.2 program의 2 개 채널로 신호를 획득 및 저장하였다. 획득한 시간영역의 근전도 신호를 주파수영역으로 변환해주기 위해서 고속 푸리에 변환을 사용했고 이를 통해 중앙 주파수와 평균 주파수의 값 을 도출하였다. 중앙 주파수와 평균 주파수를 구하는 공식은 아래와 같다. MDF는 $\mathrm{EMG}$ 전력 스펙트럼이 동일한 전력을 가진 두 영역으로 구분되는 주파수 값으로 여기서 Pj라고 표현할 수 있다. 주파수 집합 (frequency bin) j에서 EMG 전력 스펙트럼이며, $\mathrm{M}$ 은 주파수 집합의 길 이이다. MNF는 EMG 전력 스펙트럼과 주파수의 곱으로 계산되는 평 균주파수 값이며 스펙트럼 강도의 총합으로 나뉜다. ${ }^{21}$

$$
\sum_{j=1}^{M D F} P_{j}=\sum_{j=M D F}^{M} P_{j}=\frac{1}{2} \sum_{j=1}^{M} P_{j} \quad M N F=\sum_{j=1}^{M} f_{j} P_{j} / \sum_{j=1}^{M} P_{j}
$$

\section{3. 자료분석}

본 연구에서 얻은 자료는 Windows용 통계프로그램을 사용하여 분 석하였다(IBM SPSS Statistics 19.0 Inc., USA). 압통역치 값 차이 분석에 는 Shapiro wilk test를 이용하여 정규성을 확인하였다. 분석한 결과 $\mathrm{p}>0.05$ 를 만족하여 정규성이 확보되어 t-test를 시행하였으며 통증유
Table 2. Comparison of pressure pain threshold by location

\begin{tabular}{lllcc}
\hline Measurement location & Side & Trigger point & Non-Trigger point & $p$ \\
\hline Upper trapezius & Right & $4.60 \pm 1.90$ & $7.24 \pm 2.20$ & $0.01^{* *}$ \\
& Left & $5.96 \pm 1.58$ & $9.10 \pm 1.94$ & $0.01^{* *}$
\end{tabular}

Sensitivity measured in $\mathrm{kg} / \mathrm{cm}^{2}$.

${ }^{*} \mathrm{p}<0.05,{ }^{* *} \mathrm{p}<0.01$

발점과 비통증유발점 위치에서의 $\mathrm{MDF}$ 및 $\mathrm{MNF}$ 차이는 표본수가 적 어 비모수 통계분석인 Mann-Whitney U test를 사용하여 비교하였다. 모든 통계학적 유의수준( $(\alpha)$ 은 0.05 로 하였다.

결 과

우측 위등세모근의 압통역치 값은 통증유발점에서 $4.60 \pm 1.90$, 비통 증유발점에서 $7.24 \pm 2.20$ 로 유의하게 $(\mathrm{p}<0.01)$ 차이가 있었다. 또한 좌 측 위등세모근의 압통역치 값도 통증유발점에서 $5.96 \pm 1.58$, 비통증 유발점에서 $9.10 \pm 1.94$ 로 유의한 차이가 있었다 $(\mathrm{p}<0.001)$ (Table 2). 압 력역치를 측정한 값에 근거하여 본 연구는 근막 통증유발점의 활성 과 비활성 근육 위치에 따른 근육 피로도를 비교하였다. 


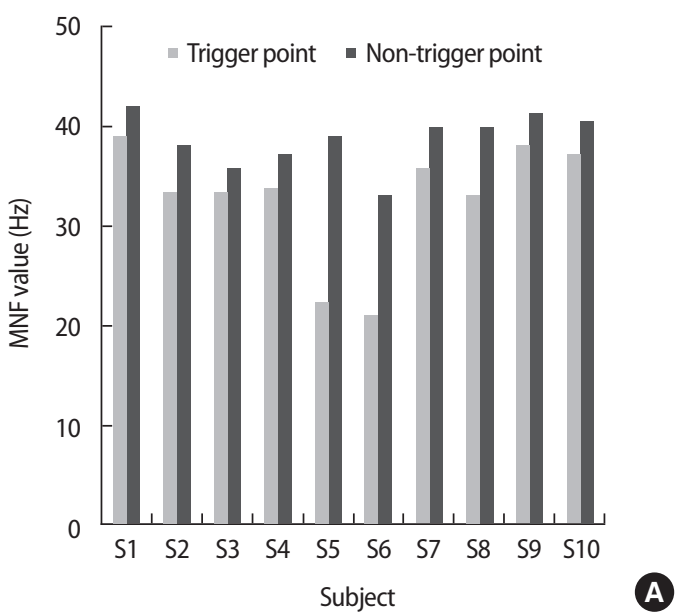

Figure 4. Results of EMG frequency analysis (A) MDF value, (B) MNF value.

Table 3. Comparison of MDF, MNF by location

\begin{tabular}{lrcc}
\hline & \multicolumn{2}{c}{ Location } & $\mathrm{p}$ \\
\cline { 2 - 3 } & Trigger point & Non-Trigger Point & \\
\hline MDF value (Hz) & & & $0.016^{*}$ \\
Mean Rank & 7.30 & 13.70 & \\
Sum Rank & 73.00 & 137.00 & $0.001^{* * *}$ \\
MNF value (Hz) & & & \\
Mean Rank & 6.30 & 14.70 & \\
Sum Rank & 63.00 & 147.00 & \\
\hline
\end{tabular}

MDF: median frequency, MNF: mean frequency.

${ }^{*} p<0.05,{ }^{* *} p<0.01,{ }^{* * *} p<0.001$

Figure 3에서 채널1은 오른쪽 위등세모근의 통증유발점의 근전도 신호이며 채널2는 비통증유발점에서 측정된 근전도 신호를 나타냈 다. 어깨올림 동작을 2 초 간격으로 30 초 동안 실시했을 때 나타나는 근 수축 원신호의 진폭은 유사한 것으로 확인하였다. 통증유발점에 서 중앙 주파수와 평균 주파수 근전도 측정 부위에서 주파수 영역의 근육 피로 비교를 한 결과 중앙 주파수와 평균 주파수 모두 통증유 발점에 비해 비통증유발점에서 크게 나타났다(Figure 4).

통증유발점의 유무에 따른 근육의 피로도의 변화를 알아보기 위 해 비모수검정인 Mann-Whitney U test를 시행한 결과 통증유발점에 서의 평균 순위(Mean Rank)와순위 합(Sum Rank)이 비통증유발점에 비해 낮게 나타남을 확인하였다 $(\mathrm{p}<0.05)$ (Table 3). 이는 통증유발점 에서 근육 피로도가 유의하게 크다는 것을 의미한다.

\section{고 찰}

현대 사회는 근골격계 피로를 유발하는 활동이 증가하면서 상당수 의 사람들에게 나타나는 통증 질환인 근막통증증후군을 경험한다. ${ }^{2}$ 근막 통증을 유발하는 원인은 통증유발점의 존재이고 진단법은 다

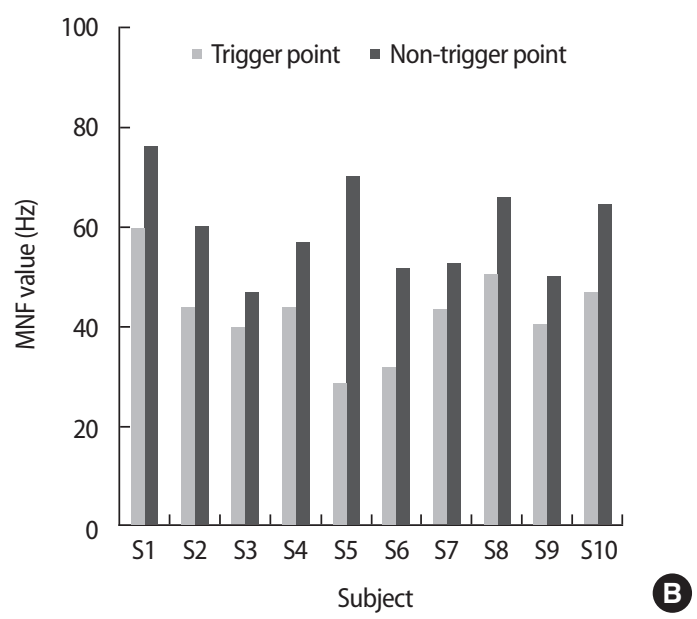

양하나, 정량적 진단법에 대한 연구는 미비한 실정이다. 따라서 본 연 구는 통증유발점의 발병학을 근거하여 근전도의 중앙 주파수와 평 균 주파수를 비교함으로써 근육의 피로도를 확인하고자 하였다. 그 결과 통증유발점과 상대적으로 비통증유발점에서 중앙 주파수와 평균 주파수가 유의하게 크게 나타났다. 이를 통해 비통증유발점보 다 통증유발점에서 근육 피로도가 높다는 사실을 확인하였다. 다시 말해서, 이는 통증유발점이 근육의 피로도를 유발하는데 관련이 있 는 것으로 사료된다.

Fischer ${ }^{12}$ 는 압력통각계 신뢰성에 관한 증거로 많이 인용되며 정보 를 객관적으로 수집할 수 있는 도구로 설명하였다. 압력통각계가 개 발된 후 근막통증증후군 환자 평가 도구로써 적합성과 나이의 상관 관계, 성별과 비활동성 역치 값 등 많은 연구들이 존재한다. 본 연구 에서도 압통역치의 변화는 John 등 22 의 연구 결과와 일치하였으며 피 실험자 10 명을 대상으로 통증유발점에서 측정한 압통역치가 비통증 유발점 보다 낮게 나타나는 것을 확인하였고 이는 통증유발점이 근 섬유 내 통증과 스트레스를 발생시키며 이러한 스트레스의 증가로 추가적 활성이 나타나기 쉬운 상태가 되었음을 의미한다. 또한 선행 연구의 표면 근전도 실험에서는 진폭의 크기를 비교하여 통증유발점 이 있는 근육이 통증유발점이 없는 근육에 비해 전기적으로 더 활동 적이라는 사실을 확인하였다. ${ }^{23}$ 이러한 선행연구의 결과는 통증유발 점의 일반적인 유무는 알 수 있으나 건강한 사람들의 모집단에서의 통증유발점과 비통증유발점의 부재를 구별할 수 없다는 한계점이 있다. 이를 보완하기 위해 해당 연구에서는 근전도 신호를 주파수 분 석을 통해 근육 피로의 크기로 나타내었다. 측정한 근전도 신호를 주 파수 분석하여 중앙 주파수와 평균 주파수를 추출했으며 두 신호 모 두 통증유발점 값이 비통증유발점에서 보다 더 감소하게 나타났다. 따라서 통증유발점의 주파수 영역에서 근전도 신호가 낮은 주파수 대역으로 이동함을 확인하였다. 이는 비통증유발점 보다 통증유발 
점에서 근육 피로도가 높으며 피로도에 자체에도 취약함을 알 수 있 었다.

본 연구의 결과를 통해 통증유발점에서의 근육 피로도가 비통증 유발점에 비해 높게 나타남을 확인하였고, 이는 근막통증증후군을 진단할 수 있는 한 방법으로 제시될 수 있을 것으로 사료된다. 또한 표 면 근전도의 다양한 주파수 분석을 활용하여 진단하는 방법은 근막 통증증후군의 원인이 되는 통증유발점의 발병학을 입증하는 요소 로 작용될 수 있으며 새로운 지표로서 기대할 수 있을 것이다.

그러나 현재 연구는 단시간 운동 시 나타나는 근육의 피로도를 분 석하였으므로 향후 연구는 장시간 운동 시 나타나는 값을 비교하는 연구가 이루어져야 할 것이다. 또한 임상관련 연구자들과의 협업을 통해 연구대상자의 수를 늘림과 동시에 근막통증증후군의 상태를 정확하게 파악하고 압통 역치를 정량적으로 분류하여 근피로도 사 이의 상관관계를 명확하게 밝혀내는 것도 필요하다. 추가적으로 본 연구의 측정 부위인 위등세모근 이외에도 통증유발점이 존재하는 부위를 세분화하여 측정해 조금 더 심도 있는 연구가 이뤄져야 할 것 이다.

\section{ACKNOWLEDGEMENTS}

본 연구는 2019년 정부(과학기술정보통신부)의 재원으로 한국연구 재단의 지원을 받아수행됨(No. NRF-2019R1F1A1060710).

\section{REFERENCES}

1. Alvarez DJ, Rockwell PG. Trigger points: diagnosis and management. Ann Fam Med. 2002;65(4):653.

2. Kim CM, Lee JK. Meta-analysis on the effect of physical therapy methods on myofascial pain syndrome: the cases of domestic research. J Kor Phys Ther. 2020;32(4):222-7.

3. Choi WJ, Nam EJ, Kim HJ et al. Effects of extracorporeal shock wave therapy with myofascial release techniques on pain, movement, and function in patients with myofascial pain syndrome. PNF \& Mov. 2020;18(2):245-54.

4. Kim MK, Lee WJ. Effect of fascial distortion model on the pain and movement of neck patient. J Kor Phys Ther. 2019;31(1):24-30.

5. Vøllestad NK. Measurement of human muscle fatigue. J Neurosci Methods. 1997;74(2):219-27.

6. Gerwin RD. Diagnosis of myofascial pain syndrome. Phys Med Rehabil Clin N Am. 2014;25(2):341-55.
7. Hong CZ. Treatment of myofascial pain syndrome. Curr Pain Headache Rep. 2006;10(5):345-9.

8. Kwon JH, Lee YH, Ok YH et al. Critical evaluation about diagnosis and treatment of myofascial trigger points. Exer Sci. 2018;27(4):245-51.

9. Lavelle ED, Lavelle W, Smith HS. Myofascial trigger points. Anesthesiol Clin. 2007;25(4):841-51.

10. Vanderweeen L, Oostendorp RAB, Vaes P et al. Pressure algometry in manual therapy. Man Ther. 1996;1(5):258-65.

11. Almuslem WH. The sympathetic nervous system effects of spinal mobilisations in those with and without chronic low back pain. Manchester Metropolitan University. Dissertation of Doctorate Degree. 2018.

12. Fischer AA. Pressure algometry over normal muscles. Standard values, validity and reproducibility of pressure threshold. Pain. 1987;30(1):11526.

13. Kelly-Martin R, Doughty L, Garkavi et al. Reliability of modified adheremeter and digital pressure algometer in measuring normal abdominal tissue and C-section scars. J Bodyw Mov. 2018;22(4):972-9.

14. Lee YH, Jung HD, Choi HH et al. Evaluation of muscle fatigue during isometric exercise depending on concentric contraction and eccentric contraction. J of RWEAT. 2012;6(1):59-65.

15. De Luca CJ. Myoelectrical manifestations of localized muscular fatigue in humans. Crit Rev Biomed Eng. 1984;11(4):251-79.

16. Basmajian JV, De Luca CJ. Muscles Alive. 5th ed. Baltimore, Williams \& Wilkins, 1985.

17. Larsson B, Månsson B, Karlberg C et al. Reproducibility of surface EMG variables and peak torque during three sets of ten dynamic contractions. J Electromyogr Kinesiol. 1999;9(5):351-7.

18. Boonstra TW, Daffertshofer A, Van Ditshuizen JC et al. Fatigue-related changes in motor-unit synchronization of quadriceps muscles within and across legs. J Electromyogr Kinesiol. 2008;18(5):717-31

19. Kim TH, Kim SY, Park HK. Effect of shoulder protraction exercise on the supine position for selective activation of the serratus anterior according to weight in winging scapula. J Korean Soc Phys Ther. 2019;31 (4):199-203.

20. Seo GJ, Park JW, Kwon Y. Comparison of the electromyographic activity in the lower trapezius muscle according to four different types of exercises in healthy adults. J Korean Soc Phys Ther. 2019;31(2):134-9.

21. Thongpanja S, Phinyomark A, Phukpattaranont $P$ et al. Mean and median frequency of EMG signal to determine muscle force based on timedependent power spectrum. Elektronika ir Elektrotechnika. 2013;19(3): 51-6.

22. Reeves JL, Jaeger B, Graff-Radford SB. Reliability of the pressure algometer as a measure of myofascial trigger point sensitivity. Pain. 1986;24 (3):313-21.

23. Wytrążek Marcin, Huber J, Lipiec J et al. Evaluation of palpation, pressure algometry, and electromyography for monitoring trigger points in young participants. J Manipulative Physiol Thera. 2015;38(3):232-43. 